Article

\title{
Evaluation of a Novel Controlled Cutting Fluid Impinging Supply System When Machining Titanium Alloys
}

\author{
Salah Gariani ${ }^{1}$, Islam Shyha ${ }^{1, *}$, Fawad Inam ${ }^{1}$ and Dehong Huo ${ }^{2}$ \\ 1 Department of Mechanical and Construction Engineering, Northumbria University at Newcastle, \\ Newcastle upon Tyne NE1 8ST, UK; salah.gariani@northumbria.ac.uk (S.G.); \\ fawad.inam@northumbria.ac.uk (F.I.) \\ 2 School of Mechanical and Systems Engineering, Newcastle University, Newcastle Upon Tyne NE1 7RU, UK; \\ dehong.huo@newcastle.ac.uk \\ * Correspondence: islam.shyha@northumbria.ac.uk; Tel.: +44-191-243-7834
}

Academic Editor: Yuyuan Zhao

Received: 11 April 2017; Accepted: 25 May 2017; Published: 29 May 2017

\begin{abstract}
Following a comprehensive review on titanium machining and methods of cutting fluid application, this paper presents a new Controlled cutting fluid impinging supply system (Cut-list) developed to deliver an accurate amount of cutting fluid into the machining zone via well-positioned coherent nozzles based on the calculation of the heat generated. The performance of the new system was evaluated against a conventional flood cutting fluid supply system during step shoulder milling of Ti-6Al-4V using vegetable oil-based cutting fluid. The comparison was performed at different cutting speeds and feed rates. Comparison measures/indicators were cutting force, workpiece temperature, tool flank wear, burr formation and average surface roughness (Ra). The new system provided significant reductions in cutting fluid consumption of up to $42 \%$. Additionally, reductions in cutting force, tool flank wear and burr height of $16.41 \%, 46.77 \%$, and $31.70 \%$ were recorded, respectively. Smaller Ra values were also found with the use of the new system.
\end{abstract}

Keywords: impinging supply system; coherent nozzle; vegetable oil-based cutting fluid; milling; Ti-6Al-4V

\section{Introduction}

Titanium and its alloys have a low machinability index and require relatively lower cutting speeds (i.e., $<90 \mathrm{~m} / \mathrm{min}$ ) due to their low thermal conductivity, low Young's modulus, strong chemical reactivity, and high hardness and dynamic shear strength at elevated temperatures $\left(>500{ }^{\circ} \mathrm{C}\right)[1-3]$. However, pushing cutting conditions boundaries in machining titanium is required for faster manufacturing [4]. Owing to low thermal conductivity such as $7.3 \mathrm{~W} / \mathrm{m} \cdot \mathrm{K}$ for annealed Ti-6Al-4V, cutting titanium generates a large amount of heat close to the machining zone. The high working hardening affinity of titanium alloys can also promote high cutting forces and temperatures, leading to tool notching and excessive tool wear [5]. Without a cutting fluid, titanium alloys are more prone to forming oxides in atmospheric environments, which can also negatively affect their mechanical properties, causing embrittlement and reduced alloy fatigue strength [6-8]. Mineral oil-based, semi-synthetic and synthetic cutting fluids are traditionally employed due to their chemical stability. Often these fluids are blended with some additives and colloidal suspensions (e.g., nanoparticles, graphene and/or graphene oxide) to improve their lubrication and cooling efficiency [9-11]. However, conventional cutting fluids are susceptible to microbial contamination due to the high content of toxic substances such as hydrocarbons, chemical agents (e.g., biocides), and Extreme Pressure (EP) additives which have adverse effects on the environment and human health (e.g., lung disorders, 
dermatitis, and cancers) [12-16]. Vegetable Oils (VOs)-based cutting fluids are superior alternatives due to their high biodegradability [17] and the distinctive chemical structure of the vegetable oil's molecules, which may be heavy, long, and dipolar in nature. Uniformity and super-density are other unique properties of vegetable oil molecules, which afford a thick, tenacious and vigorous film layer that offers VOs a superior ability to absorb contact pressure [18-22]. VOs base stocks have high thermal conductivities of up to $0.172 \mathrm{~W} / \mathrm{m} \cdot \mathrm{K}$ and a low coefficient of friction (e.g., 0.03 for soybean oil) compared to $0.125 \mathrm{~W} / \mathrm{m} \cdot \mathrm{K}$ and 0.07 , respectively, for mineral oils [23-25]. An adequate understanding of cutting fluid application methods in machining operations may significantly enhance heat dissipation and thus improve the surface quality of machined parts. Several cooling supply methods were introduced to control the temperature in the cutting zone to improve productivity and increase the overall performance of machining processes. Six main cooling strategies are used in machining operations [26,27]. Conventional flood/wet cooling is a common supply method used in machine shop floors. This method provides a steady-state stream of fluid to the machining zone with flow rates ranging from $10 \mathrm{~L} / \mathrm{min}$ for single point tools to $225 \mathrm{~L} / \mathrm{min}$ for multiple tool cutters [28]. Flood cooling was evaluated against minimum quantity lubrication (MQL) and dry cutting while turning hardness steel (EN-31). A reduction (about 57.14\%) in the chip-tool interface temperature was obtained when flood cooling was used [29]. However, high cutting fluid consumption and low fluid penetration, particularly at higher cutting speeds, are the main drawbacks [30]. High pressure cooling (HPC) was also introduced where cutting fluids are applied at high pressure up to 200 bars through customised nozzles to provide a powerful jet of fluid into the machining zone. The cooling performance of HPC was compared with flood cooling during cutting Inconel 718 using the SiAlON cutting tool. It was found that HPC was immensely helpful to extend tool life and improve chip breaking [31]. However, the high cost of pumping systems and equipment for micro-particle filtering (i.e., $<20 \mu \mathrm{m}$ ) are the main disadvantages [30,32]. Minimum quantity lubrication (MQL), compressed air, oil mist and cryogenic cooling were also considered as alternative cooling supply techniques to reduce the amount of cutting fluid delivered. MQL was found a useful lubricating method to enhance surface quality and tool life, while cryogenic cooling was found very effective in reducing tool wear and lengthening tool life. However, high costs associated with these cutting fluid supply systems are the principal limitation [33-37].

Additionally, nozzle position plays a vital role in machining operations and considerably affects tool life and cutting performance. Lopez et al. [38] studied the influence of nozzle positions of $45^{\circ}$ and $135^{\circ}$ in relation to feed direction when milling Al5083 using the MQL cooling supply method. The results showed that the nozzle position at $135^{\circ}$ achieved lower tool flank wear of 0.098 and $0.095 \mathrm{~mm}$ at 0.04 and $0.06 \mathrm{ml} / \mathrm{min}$ cooling rates, respectively. The $45^{\circ}$ nozzle orientation showed inferior flank wear values of 0.14 and $0.12 \mathrm{~mm}$ at 0.04 and $0.06 \mathrm{ml} / \mathrm{min}$, respectively, after a $158 \mathrm{~m}$ cutting length. It was found that nozzle placement is crucial in order to obtain the optimum effect of MQL cooling. Similarly, the $45^{\circ}$ nozzle angle assisted in increasing tool life $9.25 \%$ compared with $90^{\circ}$ nozzle angle when end-milling aged Inconel 718 under $\mathrm{MQL}+\mathrm{CO}_{2}$ cooling using laval coolant nozzles [39]. A recent study [40] has concluded that a $12.5^{\circ}$ orientation angle increased tool life by $50 \%$ with average flank wear below $0.3 \mathrm{~mm}$ compared to that of $45^{\circ}$ when high-speed milling of H13 steel using the MQL supply system. Supplying cutting fluid with and against feed direction has also been investigated [41] when micro-milling Ti-6Al-4V using MQL and jet application cooling. Tool wear values were found to be about $1.6 \%$ less with feed direction in MQL compared to $6.15 \%$ with jet cooling. Liu et al. [42] found that an MQL spraying nozzle position of $135^{\circ}$ and a spraying distance of $25 \mathrm{~mm}$ helped to reduce cutting temperature by 2.5 and $20^{\circ} \mathrm{C}$ compared to $90^{\circ}$ nozzle angle and $45 \mathrm{~mm}$ spraying distance, respectively. Another recent work by [43] has investigated the effect of a new sensor-based cutting fluid supply system on machined surface quality using minimum quantity fluid MQF cooling. The new system was evaluated against a conventional flood, high quantity flood cooling (HQF at $36 \mathrm{~L} / \mathrm{hr}$ ) and dry cutting conditions. The trials were performed on AISI 1045 steel utilising chemical vapour deposition (CVD) coated cutting tools and semi-synthetic cutting fluid (MicroSol 585 XT). Tests were 
carried out at a cutting speed of $225 \mathrm{~m} / \mathrm{min}$, a feed rate of $0.1 \mathrm{~mm} / \mathrm{rev}$ and depth of cut of $1.2 \mathrm{~mm}$. The results showed that lower surface roughness (Ra) value was obtained using MQF mode $(0.488 \mu \mathrm{m}$ when targeting the fluid on the tool flank and rake face) while traditional flood, HQF, and dry cutting conditions produced Ra values of $0.637,0.689$ and $0.720 \mu \mathrm{m}$, respectively. To date, most attention has been paid to the less fluid consumption supply systems, particularly MQL in trying to reduce cutting fluid quantity in the machining operations. Regardless of the cost of this supply system and installation, this method was considered as a lubricating method rather than cooling. This inferior cooling capacity confines the potency of MQL, especially in machining of refractory materials such as titanium and nickel alloys where the heat dissipation is paramount [35]. Additionally, the issue of random estimation of the fluid flow rate during the cutting process under all previously mentioned supply methods opened a new avenue for developing a cost-effective and efficient (i.e., high cooling ability with minimum fluid waste) supply system. The developed system (a controlled cutting fluid impinging supply system, Cut-list) was designed to provide an accurate quantity of cutting fluid based on accurate heat generation calculation via well-targeted and controlled bespoke coherent nozzles.

The novelty of the proposed supply system relies on synchronisation between the calculated generated heat in machining zone with the exact required cutting fluid quantity to reduce its consumption and at the same time improving the machinability of titanium alloys. Additionally, the developed system can be integrated into existing machine tools, making it immensely attractive in less fluid consumption machining applications without the need to purchase a new machine tool.

Thus, the aim of the present work is to evaluate the performance of Cut-list with bench marking against a conventional flood supply system. Both systems were tested at similar machining conditions and key process indicators assessed include cutting force, workpiece temperature, tool flank wear, burr formation and surface finish. Both systems were employed during shoulder milling of Ti-6Al-4V using a vegetable oil-based cutting fluid.

\section{Development of the Controlled Cutting Fluid Impinging Supply System (Cut-List)}

The fluid is conveyed by means of a closed loop coolant pump (Gusher vertical immersion VBV series type, Max 1.5 bar, Gusher Pump Ltd., Wolverhampton, UK) positioned close to the cutting fluid tank to minimise the fluid pressure drop, as shown in Figure 1. The output flow rate and pressure were controlled using a valve to provide the required flow rate at any given pressure. During fluid circulation, the flow is monitored by a digital flow meter and installed at a distance of $300 \mathrm{~mm}$ from the coolant pump to ensure steady-state flow conditions. Additionally, a digital liquid pressure gauge was installed directly after the in-line filter to measure the total pressure of the cutting fluid delivered. Two dual scale-type pressure gauges were also mounted before the cutting fluid entered the nozzles to observe any pressure drops in the cutting fluid pipe at these positions. Cut-list has an ability to target fluid in feed and against feed directions simultaneously. The angled overhead nozzle ring was placed on a vertical spindle head holding two nozzles for supplying fluid at three different impinging angles of $15^{\circ}, 45^{\circ}$ and $60^{\circ}$ in the feed direction and of $15^{\circ}, 45^{\circ}, 60^{\circ}$ against feed direction, as shown in Figure 2. The new system was also designed to align nozzles in tool-workpiece engagement point at any given elevation angle relative to spindle axis using movable angled nozzle clamps and angled mounting wedges. In addition, the design of the movable nozzle clamps allows the nozzle discharge tips to be relocated away from the machining zone at different stand-off/impinging distances (e.g., 35, 55 and $75 \mathrm{~mm}$ ). 


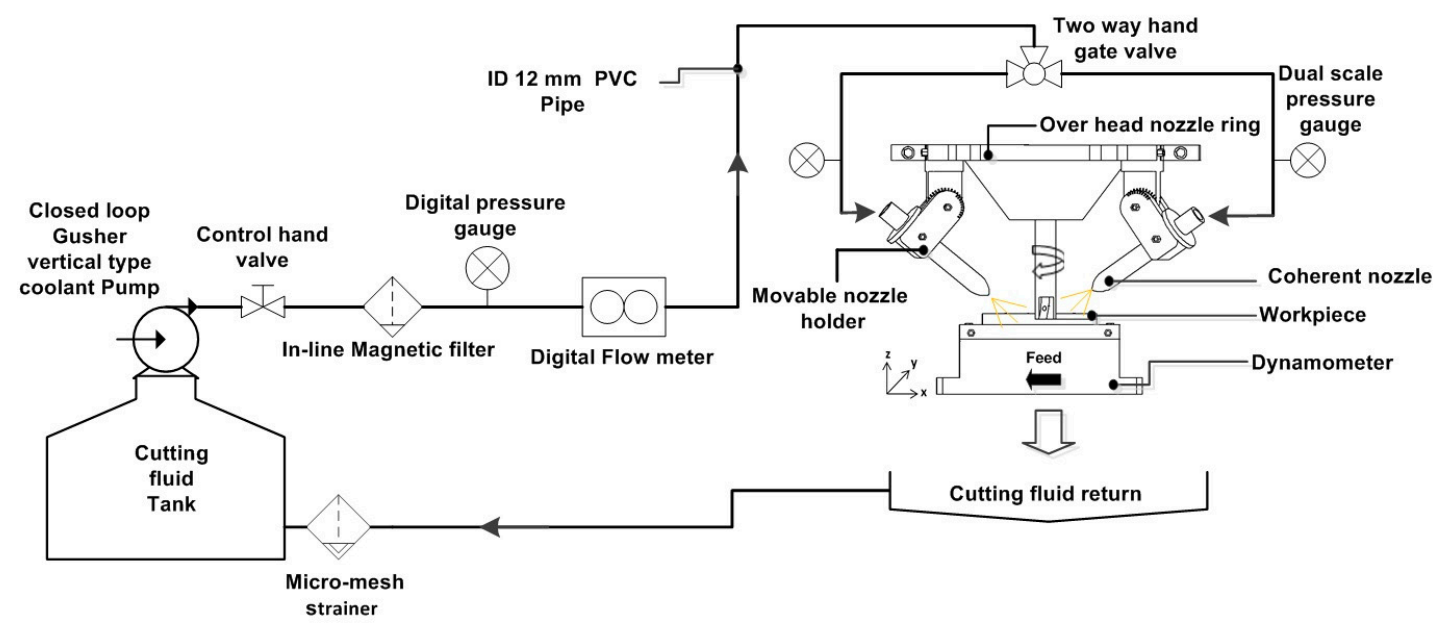

Figure 1. Schematic of the new controlled cutting fluid impinging supply system (Cut-list).

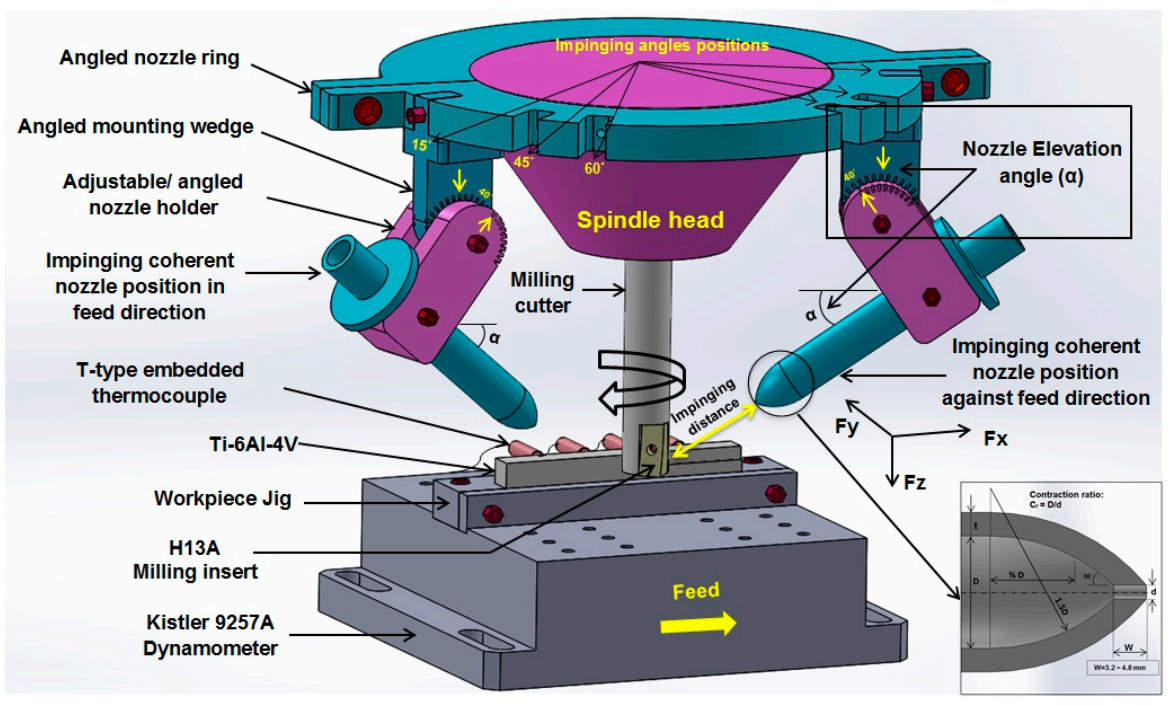

Figure 2. Schematic view for the step shoulder milling setup.

\subsection{Nozzle Design}

Coherent round nozzles can increase the dynamic pressure (kinetic energy) by $400 \%$ in the form of a combined homogenous jet up to $300 \mathrm{~mm}$ long [44,45]. Unlike traditional sloped nozzles used in conventional flood cutting fluid supply systems, the new system's nozzles were designed based on the Webster nozzle [44] to generate a high-quality coherent jet stream that affords low misting and minimum entrained air within the jet. These features will help the Cut-list effectively propel fluid further into the machining zone. The contraction ratio (inlet to exit diameter ratio) was set at more than 2:1 to achieve high jet stream quality [46]. Table 1 details dimensions of the bespoke coherent round nozzle used throughout the work. The nozzles were made from polylactic acid (PLA) plastic and rigid opaque photopolymers.

Table 1. Internal dimensions of bespoke coherent round nozzle used during experiments.

\begin{tabular}{cc}
\hline Dimension & Value \\
\hline Nozzle aperture diameter $(d)$ & $1.75 \mathrm{~mm}$ \\
Nozzle thickness $(t)$ & $2.5 \mathrm{~mm}$ \\
Internal diameter of the nozzle feed pipe $(D)$ & $12 \mathrm{~mm}$ \\
Contraction ratio $(D / d)$ & $6.85: 1$ \\
\hline
\end{tabular}




\subsection{Theoretical Work}

\subsubsection{Computation of Cutting Energy and Accurate Flow Rate}

Step shoulder-down milling was chosen as a cutting strategy for evaluating the new system, as shown in Figure 3. Equations (1)-(3) were used to calculate metal removal rate (MRR), table speed and total cutting energy, respectively $[47,48]$. In step shoulder or side milling, where the cutter diameter (Dc) is larger than the radial depth of cut $\left(a_{e}\right)$, the table speed should be adjusted to avoid chip thinning effects. The final equation of table speed was then expressed as in Equation (2). The total cutting energy was then determined as per Equation (3).

$$
\begin{gathered}
M R R=V_{f} * a_{p} * a_{e} \\
V_{f}=f * Z * N * K_{1} \\
P_{c}=\frac{U * M R R}{60}
\end{gathered}
$$

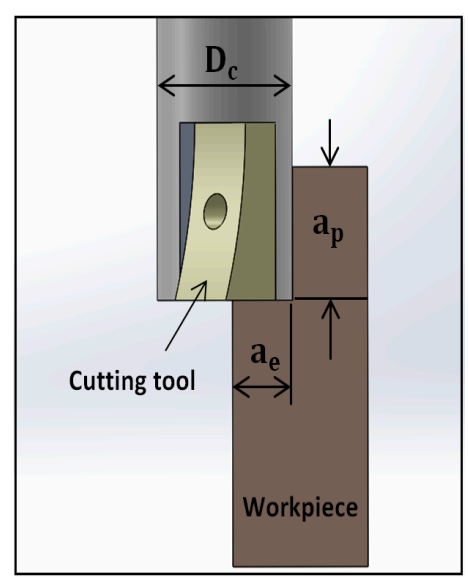

Figure 3. Schematic of step shoulder milling of Ti-6Al-4V.

During metal cutting, energy is used to deform the chip and to overcome friction in the tool and workpiece and tool-chip interfaces. A great proportion of this energy (i.e., 90-98\%) is typically converted into heat, whereas the remaining energy is retained as elastic energy in the chip [49-53]. In the present work, $90 \%$ of the total cutting energy is assumed to be converted to heat (i.e., total heat generated in the primary, secondary and tertiary deformation zones). The accurate flow rate of the cutting fluid required to cool the machining zone was then computed according to Equation (4) [54].

$$
Q_{a c c}=\frac{60 * P_{c}}{4.148 * C * \rho * \eta_{\text {nozzle }} * \Delta \theta}
$$

The inputs to calculate an accurate flow rate at different working conditions are presented in Table 2. Additionally, from a practical standpoint, the conventional flood calculations were based on $13 \mathrm{~L} / \mathrm{min}$ per $(\mathrm{kW})$ for cutting titanium as recommended by KENNAMETAL [55]. The calculation outcomes show that the fluid can be supplied at a flow rate of $8 \mathrm{~L} / \mathrm{min}$ per $(\mathrm{kW})$ using the Cut-list with a reduction in cutting fluid consumption by up to $42 \%$ compared to the conventional system (see Table 3). 
Table 2. Working conditions and values used for accurate flow rate calculations.

\begin{tabular}{cc}
\hline Inputs & Corresponding Value \\
\hline Cutting speed $(\mathrm{m} / \mathrm{min})$ & 95,200 \\
Feed rate $(\mathrm{mm} / \mathrm{rev})$ & $0.1,0.15$ \\
Axial and radial depth of cut $(\mathrm{mm})$ & $5,1.3$ \\
Cutting length $(\mathrm{mm})$ & 103 \\
Specific cutting energy $\left(\mathrm{W} . \mathrm{s} / \mathrm{mm}^{3}\right)$ & $4[56]$ \\
Cutter diameter $(\mathrm{mm})$ & 18.5 \\
Number of inserts & 1 \\
Compensation factor $\left(\mathrm{K}_{1}\right)$ & $1.96[57]$ \\
$\eta_{\text {nozzle }}$ & 0.95 \\
$\Delta \theta\left({ }^{\circ} \mathrm{C}\right)$ & $2[58]$ \\
$\rho$ fluid mass density at $10 \%$ concentration ratio $\left(\mathrm{g} / \mathrm{m}^{3}\right)$ & 0.988 \\
$C$ fluid specific heat at $10 \%$ concentration ratio $\left(\mathrm{cal} / \mathrm{g} \cdot{ }^{\circ} \mathrm{C}\right)$ & 0.948 \\
\hline
\end{tabular}

Table 3. Flow rate results for the two systems.

\begin{tabular}{ccccc}
\hline \multirow{2}{*}{$\begin{array}{c}\text { Cutting Speed } \\
(\mathbf{m} / \mathbf{m i n})\end{array}$} & $\begin{array}{c}\text { Feed Rate } \\
(\mathbf{m m} / \mathbf{r e v})\end{array}$ & $\begin{array}{c}\text { Heat Generated } \\
(\mathbf{k W})\end{array}$ & \multicolumn{2}{c}{ Calculated Flow Rate (L/min) } \\
\cline { 4 - 5 } & & & Cut-list & Conventional System \\
\hline 95 & 0.1 & 0.124 & 1 & 1.6 \\
95 & 0.15 & 0.187 & 1.5 & 2.4 \\
200 & 0.1 & 0.262 & 2.1 & 3.4 \\
200 & 0.15 & 0.393 & 3.1 & 5.2 \\
\hline
\end{tabular}

\subsubsection{Determination of Nozzle Aperture Diameter and Impinged Fluid Velocity}

The simplified version of Bernoulli's equation was utilised to determine the relationship between pressure and velocity taking into consideration the cutting fluid specific gravity as shown in Equation (5) [44,59]. Also, at a given flow rate and impinging cutting fluid velocity, the exit circular area of coherent round nozzle A can be computed using the continuity Equation (6) [59]. Fluid velocities and the minimal required nozzle aperture diameters that fulfil the above-mentioned equations were computed. Pressures were measured by the digital pressure gauge at given flow rates resulting from Equation (6), and results are shown in Table 4.

$$
\begin{aligned}
& \Delta P=\frac{S G \times V j^{2}}{535824} \\
& A=\frac{19.25 \times Q_{n}}{C D \times V j}
\end{aligned}
$$

Table 4. Results of the minimal nozzle apertures diameters and impinged fluid velocities.

\begin{tabular}{ccccc}
\hline $\begin{array}{c}\text { Cutting Fluid } \\
\text { Pressure (bars) }\end{array}$ & $\begin{array}{c}\text { Impinged Fluid } \\
\text { Velocity }(\mathbf{m} / \mathbf{s})\end{array}$ & $\begin{array}{c}\text { Fluid Specific } \\
\text { Gravity }\end{array}$ & $\begin{array}{c}\text { Minimal Nozzle Aperture } \\
\text { Diameter }-\boldsymbol{d}_{\text {min }}(\mathbf{m m})\end{array}$ & $\begin{array}{c}\text { Accurate Flow } \\
\text { Rate (L/min) }\end{array}$ \\
\hline 0.34 & 5.86 & 0.988 & 1.42 & 1 \\
0.55 & 7.46 & 0.988 & 1.50 & 1.5 \\
0.78 & 8.88 & 0.988 & 1.62 & 2.1 \\
1.16 & 10.83 & 0.988 & 1.75 & 3.1 \\
\hline
\end{tabular}

To fulfil the flow coherency criterion, the contraction ratio $(D / d)$ should be at least $\geq 2: 1$ and the actual nozzle aperture diameter $(d)$ must be $\geq$ the theoretical minimal coherent nozzle aperture diameter $\left(d_{\min }\right)$ in order to ensure the delivery of the required amount of cutting fluid [59]. For achieving the highest jet stream quality, the actual nozzle aperture diameter $(d)$ was fixed at $1.75 \mathrm{~mm}$ for all trials, whereas the contraction ratio was set at about 6.85:1 based on the calculated 
nozzle aperture diameter (i.e., $1.75 \mathrm{~mm}$ ) and the given nozzle internal feed pipe diameter (i.e., $12 \mathrm{~mm}$ ) which satisfy the flow coherency criterion.

\section{Experimental Work}

The experimental work mainly focused on the comparison between the Cut-list and the conventional system when both were tested at four different machining settings ( 2 cutting speeds and 2 feed rates). Because the new system has more settings capability compared to any conventional system, Cut-list was initially evaluated at 3 impinging angles in the feed direction, 3 impinging angles against feed direction and 3 stand-off/impinging distances, giving 27 tests at each setting of cutting speed and feed rate. Only the best trial (setting of impinging angles positions in feed and against feed direction and stand-off/impinging distance that gave best responses in terms of lowest Ra, etc.) of each of the 27 tests was used for the comparison with the conventional system. On the other hand, the conventional system was only tested in four different tests (cutting speed and feed rate were investigated at two levels each: 95, $200 \mathrm{~m} / \mathrm{min}$ and $0.1,0.15 \mathrm{~mm} / \mathrm{rev}$ respectively. Nozzle elevation angle $(\alpha)$ was $40^{\circ}$ for all trials. Experiments were performed on a CNC Cincinnati 750-Sabri vertical machining centre (Cincinnati Machine UK Ltd., Birmingham, UK, 1997) with a maximum spindle speed of $8000 \mathrm{rpm}$ and an $11 \mathrm{~kW}$ drive motor. Step shoulder-down milling experiments were carried out on annealed Ti-6Al-4V ASTM B 265 grade 5 samples in the form of a $103 \times 25 \times 11 \mathrm{~mm}$ block. Each trial involved a cutting length of $103 \mathrm{~mm}$ and a new cutting insert was used.

Coarse grain uncoated carbide milling inserts were used. Sandvik H13A (R390-11 T3 08M-KM) inserts were mounted on an $\varnothing 18.5 \mathrm{~mm} \times 110 \mathrm{~mm}$ long square shoulder milling tool holder with an overhang distance of $60 \mathrm{~mm}$ to eliminate chatter. A single tooth cutter (Sandvik Coromant, Halesowen, UK) was used to avoid the influence of tool run-out on tool wear measurements. The inserts had a nose radius of $0.8 \mathrm{~mm}, 90^{\circ}$ lead angle, and positive rake angle. A water-miscible cutting fluid (Vasco1000, Jemtech Ltd., East Sussex, UK) containing $45 \%$ pure vegetable oil $\left(950 \mathrm{~kg} / \mathrm{m}^{3}\right.$ mass density and $53.2 \mathrm{cP} @ 40{ }^{\circ} \mathrm{C}$ dynamic viscosity) was used. The fresh cutting fluid was blended at the $10 \%$ concentration ratio and was regularly checked using a hand-held refractometer (Cromwell Tools, Luton, UK). The thermal and physical properties of the blended VO-based fluid were; $988 \mathrm{Kg} / \mathrm{m}^{3}$ mass density, $1.8 \mathrm{cP}$ at $25{ }^{\circ} \mathrm{C}$ dynamic viscosity, and $3.97 \mathrm{~J} / \mathrm{g} /{ }^{\circ} \mathrm{C}$ average heat capacity. Average surface roughness $(\mathrm{Ra})$ of the machined samples was measured using a Taylor Hobson Surtroni 3+ (Taylor Hobson UK, Leicester, UK). All Ra measurements were conducted in accordance with ISO 4287 and ISO 4288 using a 0.8-mm cut-off and an evaluation length of $4 \mathrm{~mm}$. An Alicona Infinite Focus G4 optical scanner (Alicona UK Ltd., Kent, UK) was also utilised to capture the average tool flank wear (VB). Average tool flank wear (VB) was measured following each trial and after cutting a 110-mm length of the titanium workpiece in accordance with the standard ISO 8688-2 (1989). Each cutting tool was used only for one test to avoid accumulation of wear from different tests. Top burr heights were measured using the digital micro-depth gauge and measurement location is shown in Figure 4. Cutting force signals were collected using a piezo-electric dynamometer (Kistler 9257A, Kistler, Winterthur, Switzerland) which was mounted under the workpiece jig and then connected to charge amplifiers, with the output signals analysed using Kistler Dynaware software (Type 2825A-02, Kistler, Winterthur, Switzerland, 2014). Workpiece temperature was measured using mineral insulated Long Sheath Plain Pot 2mt PFA (T-type) thermocouple sensors (TEMPCON, West Sussex, UK, 2016). Four T-type thin sensing probes of $\varnothing 1.0 \mathrm{~mm} \times 10 \mathrm{~mm}$ probe length $\times 2 \mathrm{~m}$ extension cable length were inserted into pre-drilled holes in each sample to measure the temperature at $0.5 \mathrm{~mm}$ from the machined surface, as shown in Figure 4. The MX-3 thermal compound (Arctic, Switzerland) with a high thermal conductivity $(8.2 \mathrm{~W} / \mathrm{m} \cdot \mathrm{K})$ and a low thermal resistance was used to minimise heat losses. To prevent the movement of thermocouples during the cutting process, all probes were well secured using a special strong thermal adhesive (Lyreco 50g). 


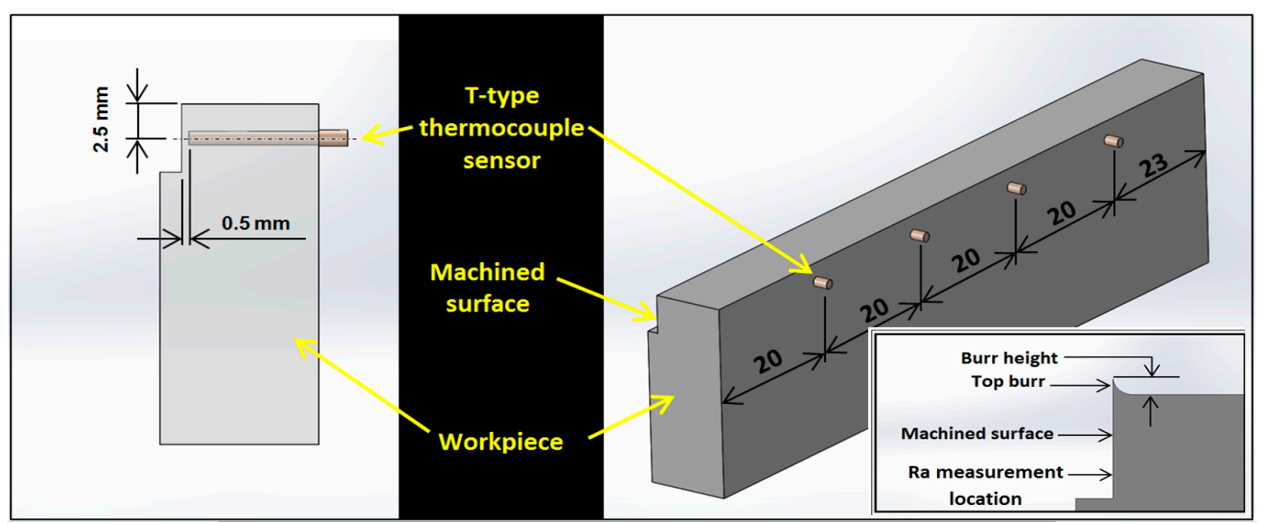

Figure 4. Thermocouple arrangement for workpiece temperature measurement (dimensions in $\mathrm{mm}$ ).

\section{Results and Discussion}

\subsection{Cutting Force}

Maximum cutting force results are shown in Figure 5. Force ranged from 1600 to $1903 \mathrm{~N}$ when the conventional system was used, while a considerable reduction in of up to $16.41 \%$ was recorded when Cut-list was employed, at a lower feed rate of $0.1 \mathrm{~mm} / \mathrm{rev}$. This could be attributed to the high adhesion action of the impinged fluid at a lower feed rate, which gave the fluid's droplets enough time to adhere to the workpiece and cutting tool surfaces. Additionally, the relatively higher impinging jet velocity (up to $10.83 \mathrm{~m} / \mathrm{s}$, see Table 4) was achievable by the Cut-list and helped the cutting fluid to penetrate effectively into the machining zone and form the boundary of the oil film between workpiece and cutter, resulting in minimising contact pressure. A similar phenomenon was reported by Ezugwu et al. [60], where the high momentum jet produced a hydraulic wedge between the tool and the workpiece interface, offering adequate lubrication with a substantial reduction in friction. In addition, the results also showed analogous trends in increasing cutting force with increased cutting speed regardless of the cooling system used. This is due to the increased cutting energy associated with increased cutting speed [61].

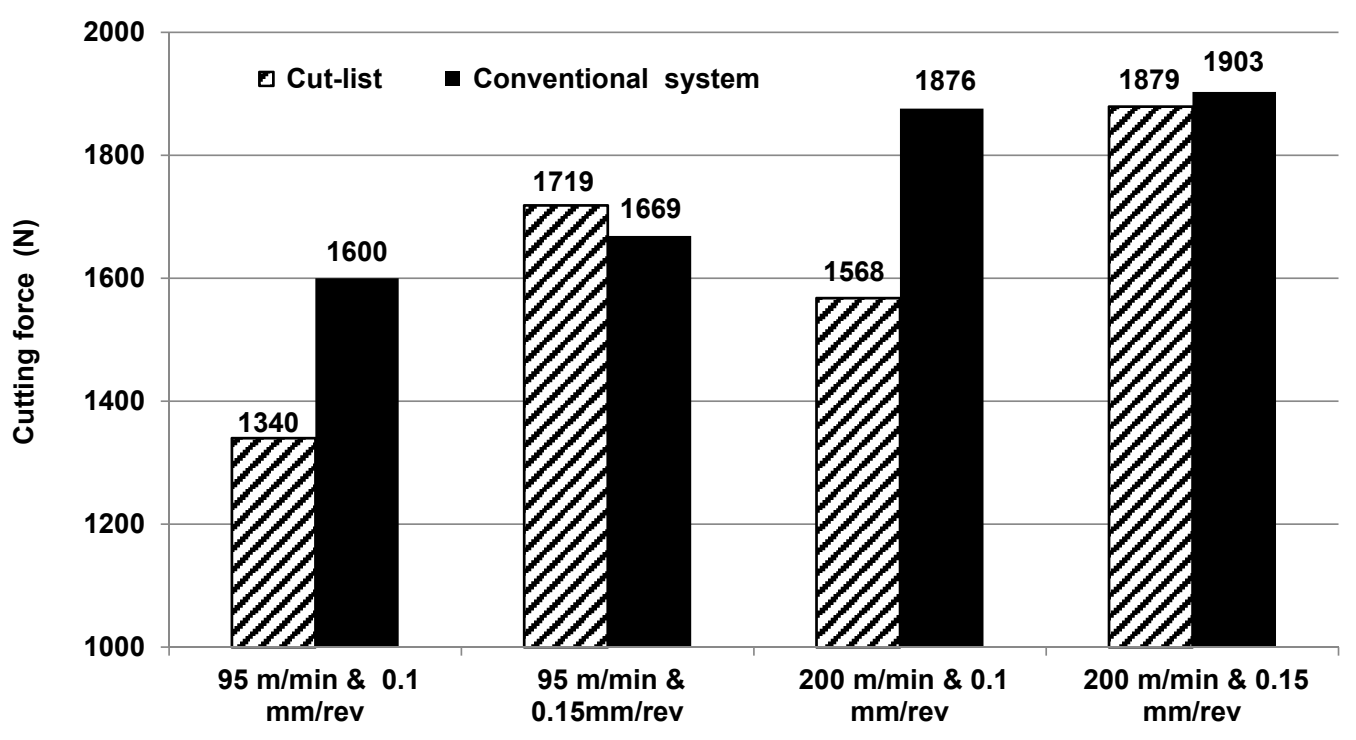

Figure 5. Cutting force results for the two systems in various cutting conditions. 


\subsection{Workpiece Temperature}

Workpiece temperature recorded for both systems at various cutting conditions are shown in Figure 6. Workpiece temperatures ranged between 20.8 and 25.7, and 20.6 and $24.2^{\circ} \mathrm{C}$, for the Cut-list and conventional systems, respectively. Seemingly, both systems showed reduced workpiece temperature with a marginal variation (maximum of $1.5^{\circ} \mathrm{C}$ ). This is likely because the small proportion ( $20 \%$ ) of the heat generated when cutting titanium is conducted into workpiece and chip while $80 \%$ of the heat is expected to transfer to cutting tool due to low thermal conductivity of titanium alloy [1]. In addition, cutting fluid can dissipate more than $30 \%$ of generated heat if it penetrates into a machining zone effectively (e.g., using high jet fluid stream at targeted heat-affected zones) [2]. Possibly, the Cut-list helped to form efficient fluid trapping between the tool and workpiece surfaces due to the nozzle positioned in the feed direction, which led to improving fluid accessibility into the machining zone, resulting in more heat transferred from the workpiece to the cutting fluid. Additionally, the impingement effect of the high-velocity fluid's droplets allowed the fluid to exert its coolant function more efficiently and thus assisted in reducing workpiece temperature. All of these helped the new system in reducing workpiece temperature and compensating the reduction (about $42 \%$, see Table 3) in the amount of cutting fluid supplied. In the same vein, both systems exhibited marginal reductions in average workpiece temperature with increased cutting speed and feed rate. This could be due to the increased fluid flow rate associated with increasing cutting energy, which improved the fluid's ability to dissipate heat $[62,63]$.

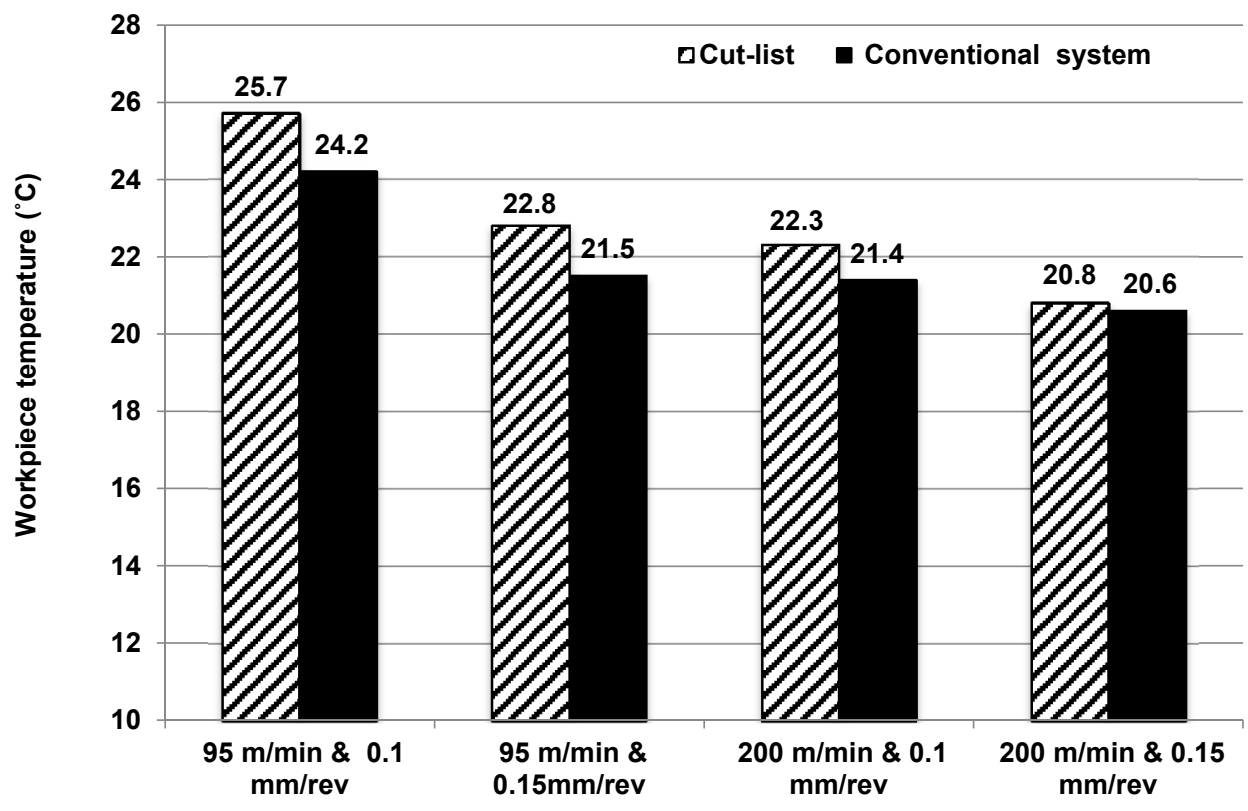

Figure 6. Workpiece temperature versus cutting conditions for the two systems.

\subsection{Tool Flank Wear}

Figure 7 demonstrates the tool flank wear data obtained for both systems in various cutting conditions. A considerable reduction in tool wear of up to $46.77 \%$ was achieved at the higher cutting speed of $200 \mathrm{~m} / \mathrm{min}$ and feed rate of $0.15 \mathrm{~mm} / \mathrm{rev}$ when using the Cut-list. In general, low flank wear levels were noticed using the Cut-list of $\sim 30 \mu \mathrm{m}$, except at $200 \mathrm{~m} / \mathrm{min}$ and $0.1 \mathrm{~mm} / \mathrm{rev}$ cutting speed and feed rate, respectively). This can be attributed to the combined cooling effect on the cutting insert in feed and against feed direction where nozzle position in feed direction helped the impinging jet to penetrate deeply into machining zone. The other position (i.e., against feed direction) afforded enough space for assisting chip evacuation and aided to cool the tool tip at end of the cyclic process. In higher cutting conditions, the Cut-list affords a larger jet velocity of $10.83 \mathrm{~m} / \mathrm{s}$, which increased the ability 
to accelerate heat dissipation from the cutting tip, thereby reducing the tool flank wear. On the other hand, the conventional supply system failed to disseminate heat sufficiently from the cutting tool at the same cutting conditions, which resulted in accelerated tool flank wear, adhesion, and micro-chipping, as shown in Figure 8.

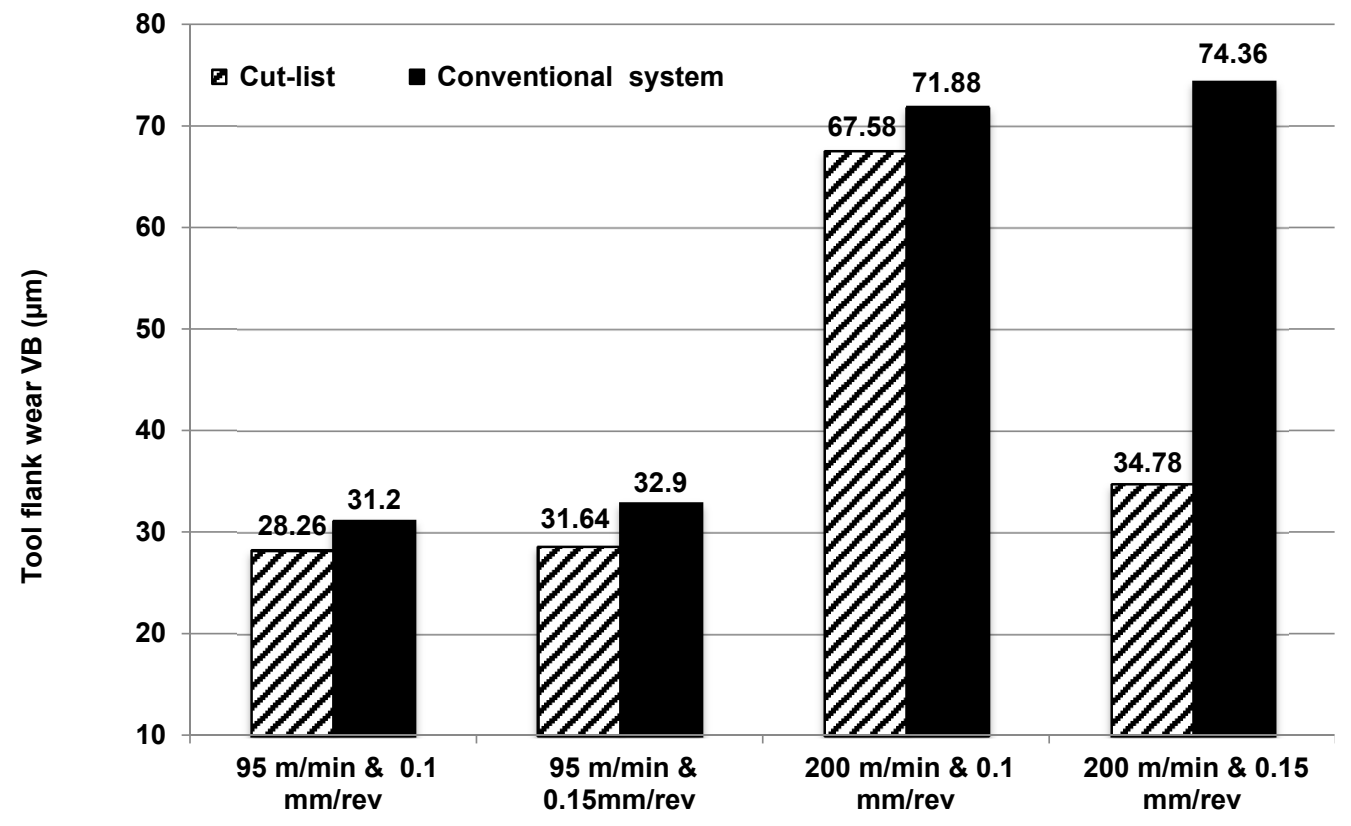

Figure 7. Tool flank wear results for the two systems.
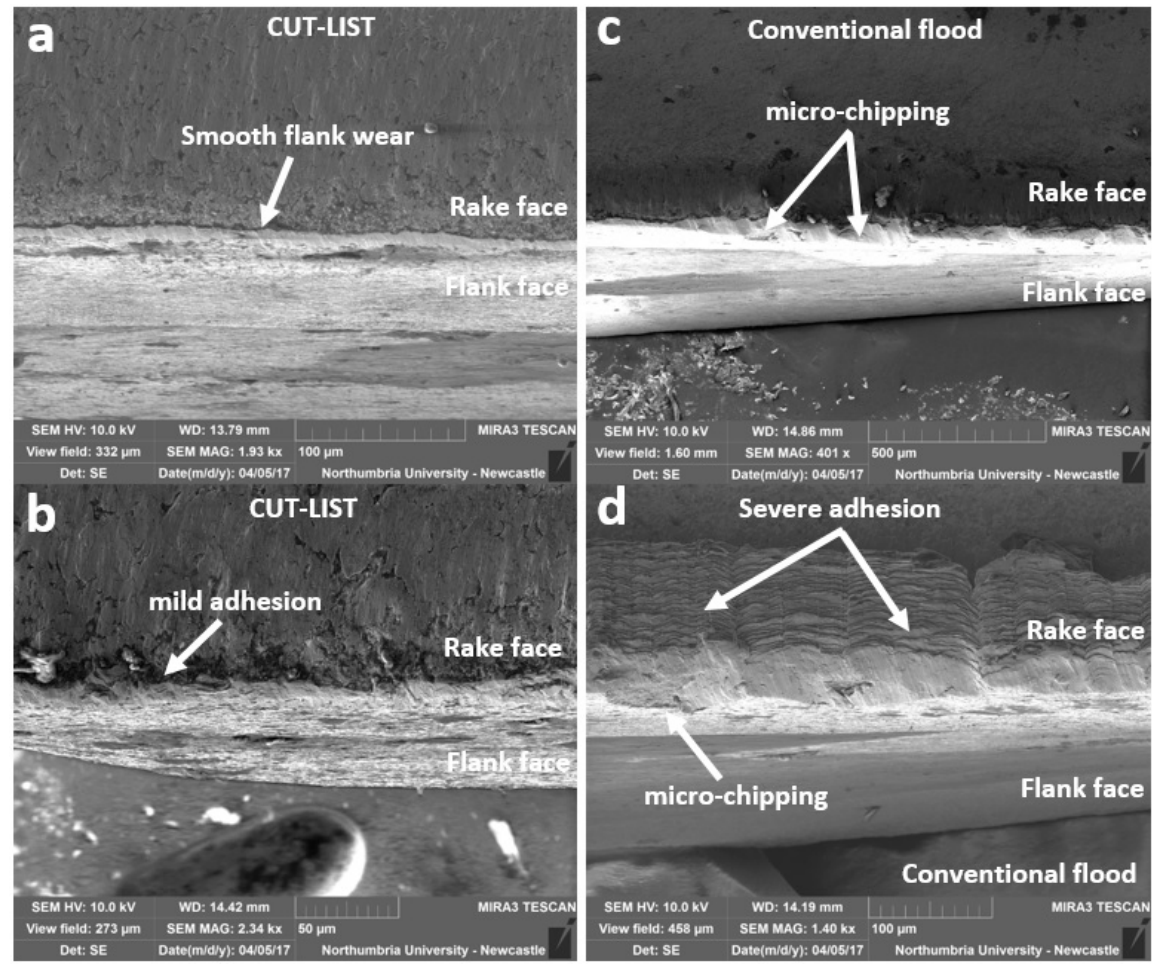

Figure 8. SEM (Scanning Electron Microscope) images of the cutting tools used with the Cut-list at feed rate of $0.15 \mathrm{~mm} / \mathrm{rev}$ and cutting speed of 95 and $200 \mathrm{~m} / \mathrm{min}$, respectively (a,b) and conventional supply system at feed rate of $0.15 \mathrm{~mm} / \mathrm{rev}$ and cutting speed of 95 and $200 \mathrm{~m} / \mathrm{min}$, respectively (c,d). 


\subsection{Burr formation}

Figure 9 details the top burr height results formed by both cutting fluid supply systems. Top burr height generated by the Cut-list was substantially smaller than that produced by the conventional cooling system, by up to $31.70 \%$. As one of the main reasons for burr formation is tool wear, the reduction of burr size is not surprising due to the reduction of tool wear discussed in the previous section. This can be also attributed to the ability of the new system to direct the high momentum impinging jet into the tool-workpiece interface that helped the jet to hit the insert edge effectively and led to maintaining the edge of the cutting tool in a sharper condition with less of a metal tearing effect. In addition, the results showed a similar trend in decreasing burr height with increased feed rate regardless of the cooling system used.

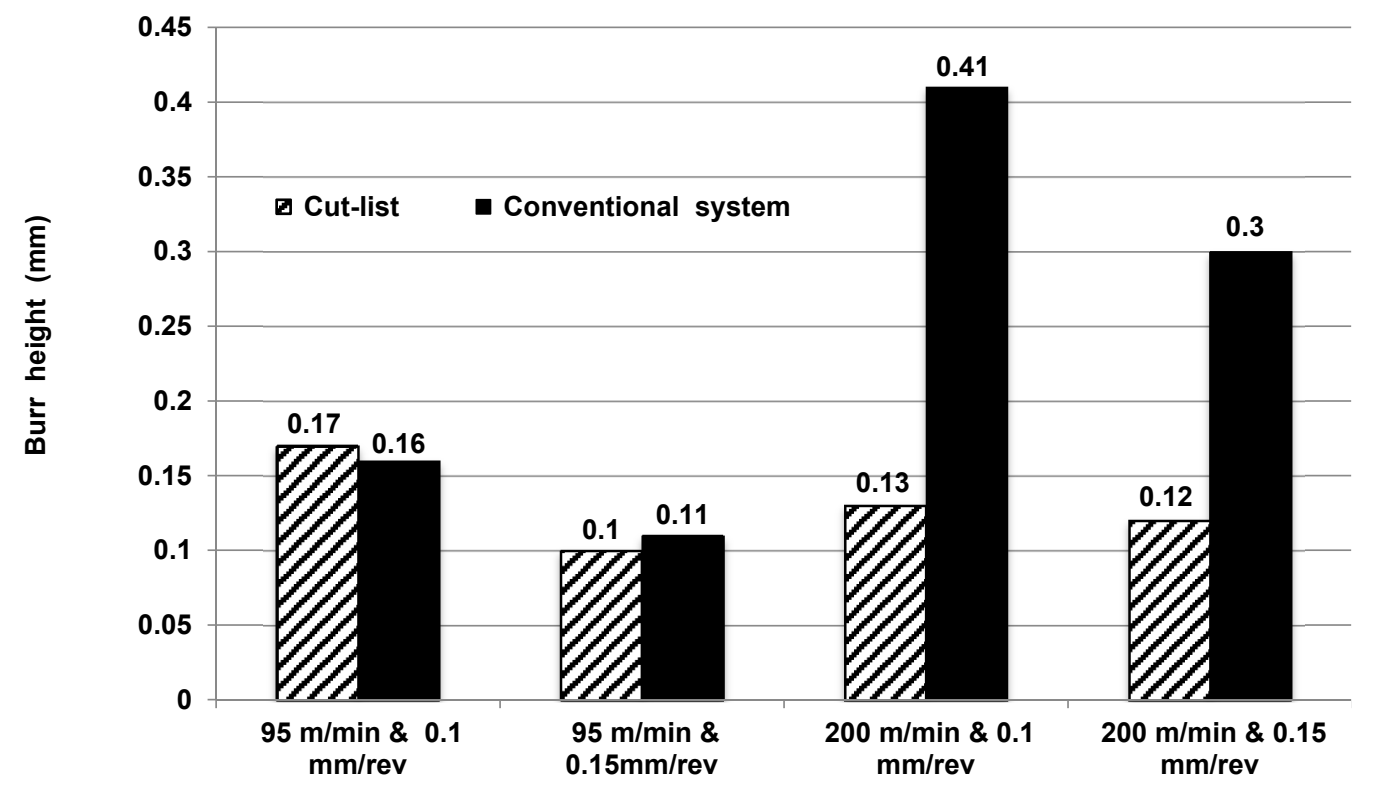

Figure 9. Effect of cutting fluid supply systems on burr height at various working conditions.

\subsection{Average Surface Roughness and Surface Quality}

Figure 10 details Ra results achieved by both systems. Surface roughness generally ranged between 0.51 and $0.56 \mu \mathrm{m}$, and 0.57 and $0.71 \mu \mathrm{m}$ for Cut-list and conventional systems, respectively. Values of Ra are relatively lower with the use of Cut-list for all conditions investigated. The new system improved the penetration of the impinged fluid for accessing the machining zone efficiently and forming the boundary of the oil film between workpiece and cutter, thereby reducing friction and improving the quality of the machined surface. Additionally, the new Cut-list and the conventional system showed similar trends in decreasing surface roughness with the increased cutting speed regardless of feed rate. This is due to the increased cutting fluid flow rate (see Table 3) associated with increased cutting speed which was found in agreement with research by Cai et al. [64]. SEM analysis showed that surfaces machined using the conventional supply systems had chips re-deposited/adhered onto the machined surfaces, as detailed in Figure 11. Feed marks were apparent on all machined surfaces regardless of the fluid supply system. No major damage such as cracks or material tearing were observed, especially when the Cut-list system was used. This is also evident with the relatively low surface roughness values. However, larger smearing was apparent when the conventional system was employed, which is likely the result of the inability of the fluid to reach machining zone, particularly at a higher cutting speed. The adhered chips observed onto the machined surfaces produced by the conventional supply system were probably the result of trapped material between tool flute, which was subsequently pressure welded to the machined surfaces due to the insufficient cutting. The findings are in agreement 
with the results by Shyha et al. [65] who reported similar observations when drilling titanium/ carbon fibre reinforced plastics (CFRP)/aluminium stacks.

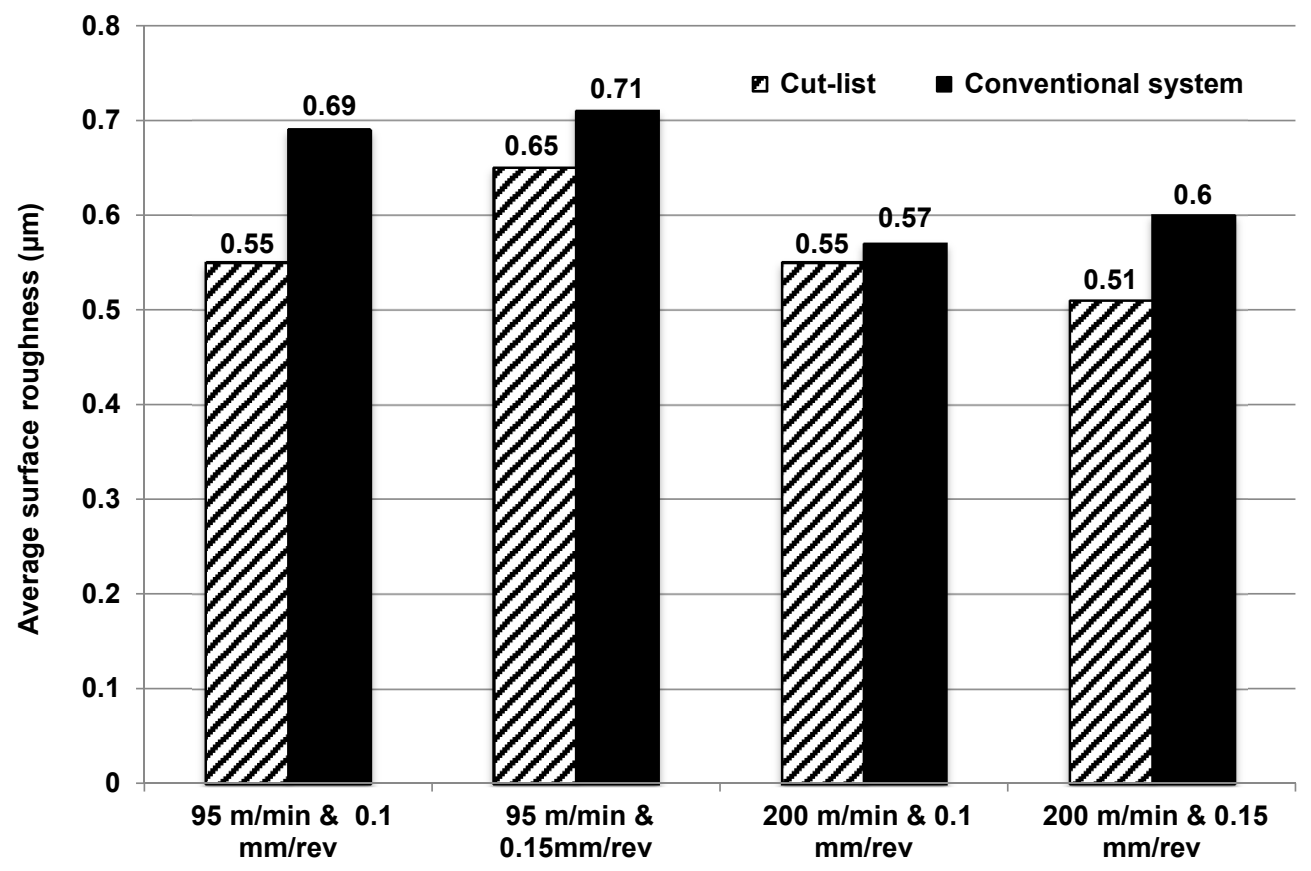

Figure 10. Average surface roughness results versus cutting conditions for the two systems.
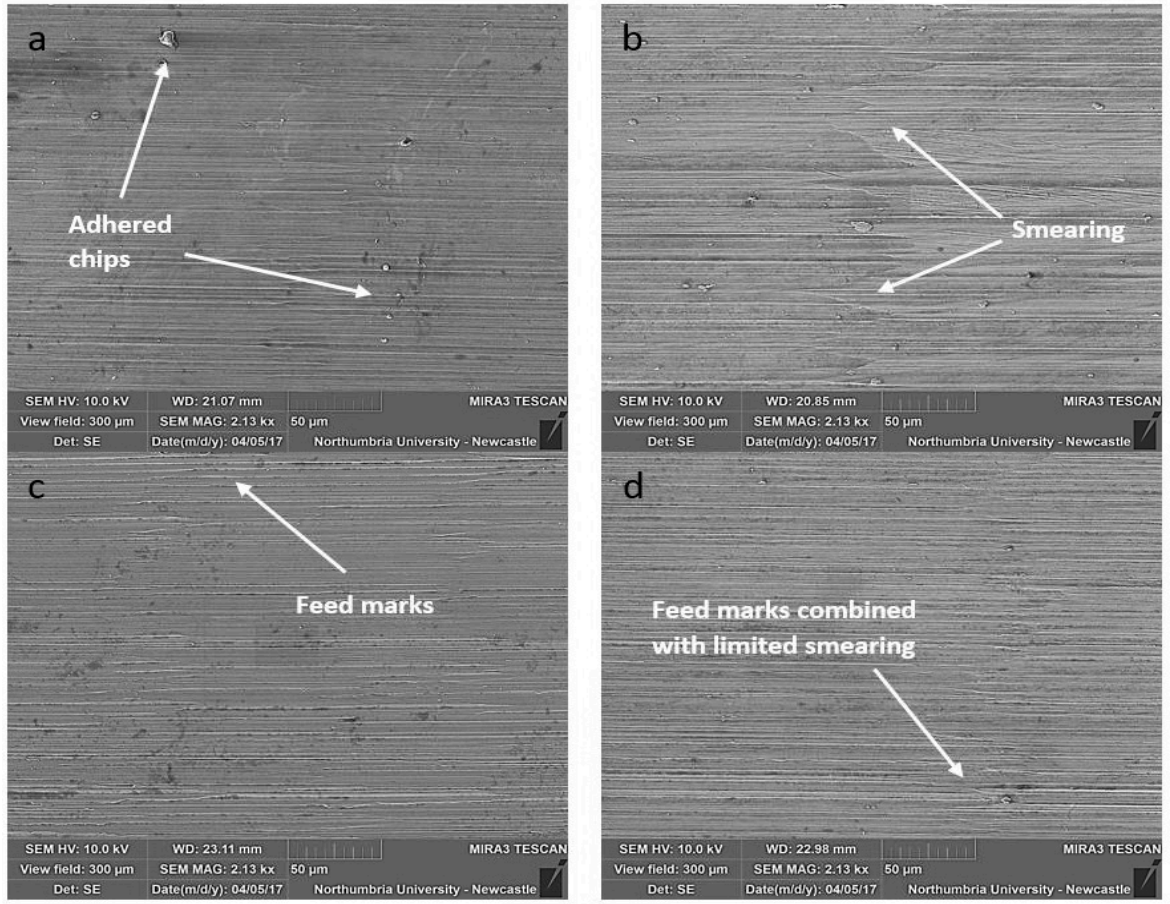

Figure 11. SEM images of surface topography for Ti-6Al-4V machined parts under conventional supply system at cutting speed of $200 \mathrm{~m} / \mathrm{min}$ and feed rate of 0.1 and $0.15 \mathrm{~mm} / \mathrm{rev}$ respectively (a,b), and Cut-list at speed of $200 \mathrm{~m} / \mathrm{min}$ and feed rate of 0.1 and $0.15 \mathrm{~mm} / \mathrm{rev}$ respectively $(\mathbf{c}, \mathbf{d})$. 


\section{Conclusions}

A new controlled cutting fluid impinging supply system (Cut-list) was designed, manufactured, and tested for machining Ti-6Al-4V using a vegetable oil-based cutting fluid. The new system performed favourably when compared to the conventional flood supply system. Based on the analysis of the experimental results, the following conclusions can be drawn:

- A total reduction of $42 \%$ in cutting fluid was achieved when the new system was employed.

- The Cut-list enabled a significant reduction in cutting force up to $16.41 \%$.

- No substantial differences were found between the two systems in workpiece temperate, although there was a significant reduction in cutting fluid consumption.

- The new system reduced tool flank wear by $46.77 \%$ compared to the tool wear measured for the conventional system at higher cutting conditions.

- Burr formation was reduced by $31.70 \%$ when employing the Cut-list.

- Ra values were relatively smaller with the use of the new system.

Precision of the collected data was checked by repeating 11 tests and measuring all key process indicators. A summary of the errors (maximum and minimum) for cutting force, workpiece temperature and tool wear responses based on the repeated tests is presented in Table 5.

Table 5. Maximum and minimum error for cutting force, workpiece temperature and tool wear.

\begin{tabular}{cccc}
\hline Experimental Error & Cutting Force & Workpiece Temperature & Tool Wear \\
\hline Maximum & $0.34 \%$ & $4.5 \%$ & $7.16 \%$ \\
Minimum & $0.03 \%$ & $0.59 \%$ & $0.8 \%$ \\
\hline
\end{tabular}

Acknowledgments: All The authors would like to thank the Department of Mechanical and Construction Engineering at Northumbria University in Newcastle for the technical support to carry out this research. The authors would also like to thank the Libyan government for financial support.

Author Contributions: Salah Gariani and Islam Shyha conceived and designed the experimental work as well as planned all measurements. Salah Gariani performed the experiments. Measurements and analysis of results were performed by Salah Gariani, Islam Shyha, Dehong Huo and Fawad Inam. Salah Garaini wrote the initial draft of the paper and Islam Shyha, Fawad Inam, Dehong Huo participated in writing the results and discussion section and revised the whole paper.

Conflicts of Interest: The authors declare no conflict of interest.

\section{Nomenclature}

$a_{p} \quad$ Axial depth of cut ( $\mathrm{mm}$ )

$a_{e} \quad$ Radial depth of cut (mm)

$V_{f} \quad$ Table speed $(\mathrm{mm} / \mathrm{min})$

$f \quad$ Feed rate $(\mathrm{mm} / \mathrm{rev})$

$N \quad$ Spindle speed (RPM)

$D_{\mathrm{c}} \quad$ Cutter diameter (mm)

$\mathrm{K}_{1} \quad$ Compensation factor as function of $\left(\frac{D_{c}}{a_{e}}\right)$

Z Number of teeth

U Specific cutting energy (W.s $/ \mathrm{mm}^{3}$ )

MRR Material removal rate $\left(\mathrm{mm}^{3} / \mathrm{min}\right)$

$P_{c} \quad$ Cutting energy (Watt)

Qacc Accurate flow rate $(\mathrm{L} / \mathrm{min})$

C Heat Capacity of the cutting fluid (cal $/ \mathrm{g} \cdot{ }^{\circ} \mathrm{C}$ )

$\rho \quad$ Mass density of the cutting fluid $\left(\mathrm{g} / \mathrm{cm}^{3}\right)$

$\eta_{\text {nozzle }} \quad$ Coherent round nozzle efficiency 
$\Delta \theta \quad$ Cutting fluid maximum tolerable temperature increase in $\left({ }^{\circ} \mathrm{C}\right)$

$\Delta P \quad$ Cutting fluid pressure (psi)

$V_{\mathrm{j}} \quad$ Cutting fluid velocity $(\mathrm{ft} / \mathrm{min})$

SG Specific gravity of the cutting fluid (i.e., density of cutting fluid

divided by the density of water)

$Q_{n} \quad$ Nozzle flow rate (gpm)

$C D \quad$ Coherent round nozzle discharge coefficient (0.95)

A Coherent round nozzle exit area $\left(\mathrm{in}^{2}\right)$

D Coherent round nozzle internal feed pipe diameter $(\mathrm{mm})$

d Coherent round nozzle aperture diameter $(\mathrm{mm})$

\section{References}

1. Ezugwu, E.O.; Batista Da Silva, R.; Falco Sales, W.; Rocha Machado, A. Overview of the machining of titanium alloys. In Reference Module in Earth Systems and Environmental Sciences; Elsevier: Amsterdam, The Netherlands, 2017.

2. Pramanik, A. Problems and solutions in machining of titanium alloys. Int. J. Adv. Manuf. Technol. 2014, 70, 919-928. [CrossRef]

3. Jaffery, S.I.; Mativenga, P.T. Assessment of the machinability of Ti-6Al-4V alloy using the wear map approach. Int. J. Adv. Manuf. Technol. 2009, 40, 687-696. [CrossRef]

4. Allwood, J.M.; Childs, T.H.; Clare, A.T.; De Silva, A.K.; Dhokia, V.; Hutchings, I.M.; Leach, R.K.; Leal-Ayala, D.R.; Lowth, S.; Majewski, C.E. Manufacturing at double the speed. J. Mater. Process. Technol. 2016, 229, 729-757. [CrossRef]

5. Elshwain, A.; Redzuan, N.; Yusof, N.M. Machinability of nickel and titanium alloys under of gas-based coolant-lubricants (cls)—A review. Int. J. Res. Eng. Technol. 2013, 2, 690-702.

6. Câmara, M.A.; Rubio, J.C.C.; Abrão, A.M.; Davim, J.P. State of the art on micromilling of materials, a review. J. Mater. Sci. Technol. 2012, 28, 673-685. [CrossRef]

7. Veiga, C.; Davim, J.; Loureiro, A. Review on machinability of titanium alloys: The process perspective. Rev. Adv. Mater. Sci. 2013, 34, 148-164.

8. Shokrani, A.; Dhokia, V.; Newman, S.T. Investigation of the effects of cryogenic machining on surface integrity in cnc end milling of Ti-6Al-4V titanium alloy. J. Manuf. Process. 2016, 21, 172-179. [CrossRef]

9. Samuel, J.; Rafiee, J.; Dhiman, P.; Yu, Z.-Z.; Koratkar, N. Graphene colloidal suspensions as high performance semi-synthetic metal-working fluids. J. Phys. Chem. 2011, 115, 3410-3415. [CrossRef]

10. Yi, S.; Li, G.; Ding, S.; Mo, J. Chips morphology analysis under graphene oxide suspension with tungsten carbide tool in drilling Ti-6Al-4V. Key Eng. Mater. 2017, 730, 289-294. [CrossRef]

11. Srikant, R.; Prasad, M.; Amrita, M.; Sitaramaraju, A.; Krishna, P.V. Nanofluids as a potential solution for minimum quantity lubrication: A review. Proc. Inst. Mech. Eng. Part B J. Eng. Manuf. 2014, 228, 3-20. [CrossRef]

12. Srikant, R.R.; Ramana, V.S.N.V. Performance evaluation of vegetable emulsifier based green cutting fluid in turning of american iron and steel institute (aisi) 1040 steel—An initiative towards sustainable manufacturing. J. Clean. Prod. 2015, 108, 104-109. [CrossRef]

13. El Baradie, M.A. Cutting fluids: Part i. Characterisation. J. Mater. Process. Technol. 1996, 56, 786-797. [CrossRef]

14. Bennett, E. Water based cutting fluids and human health. Tribol. Int. 1983, 16, 133-136. [CrossRef]

15. Kumar Gajrani, K.; Ravi Sankar, M. Past and current status of eco-friendly vegetable oil based metal cutting fluids. Mater. Today Proc. 2017, 4, 3786-3795. [CrossRef]

16. Madanchi, N.; Thiede, S.; Herrmann, C. Functional and environmental evaluation of alternative disinfection methods for cutting fluids. Procedia CIRP 2017, 61, 558-563. [CrossRef]

17. Chauhan, P.S.; Chhibber, V.K. Non-edible oil as a source of bio-lubricant for industerial applications: A review. Int. J. Eng. Sci. Innov. Technol. (IJESIT) 2013, 2, 299-305.

18. Sunday, A.L.; Imtiaz, A.Z.; Ibrahim, O.S.; Adedipe, O. Vegetable-oil based metalworking fluids research developments for machining processes: Survey, applications and challenges. Manuf. Rev. 2014, 1, 22.

19. Belluco, W.; De Chiffre, L. Performance evaluation of vegetable-based oils in drilling austenitic stainless steel. J. Mater. Process. Technol. 2004, 148, 171-176. [CrossRef] 
20. Kuram, E.; Ozcelik, B.; Demirbas, E. Environmentally friendly machining: Vegetable based cutting fluids. In Green Manufacturing Processes and Systems; Springer: Berlin, Germany, 2013; pp. 23-47.

21. Sunday, A.L.; Choudhury, I.A.; Nukman, Y. Application of vegetable oil-based metalworking fluids in machining ferrous metals-A review. Int. J. Mach. Tools Manuf. 2012, 52, 1-12.

22. Nagendramma, P.; Kaul, S. Development of ecofriendly/biodegradable lubricants: An overview. Renew. Sustain. Energy Rev. 2012, 16, 764-774. [CrossRef]

23. Nandy, A.K.; Gowrishankar, M.C.; Paul, S. Some studies on high-pressure cooling in turning of Ti-6Al-4V. Int. J. Mach. Tools Manuf. 2009, 49, 182-198. [CrossRef]

24. Siniawski, M.T.; Saniei, N.; Adhikari, B.; Doezema, L.A. Influence of fatty acid composition on the tribological performance of two vegetable-based lubricants. J. Synth. Lubr. 2007, 24, 101-110. [CrossRef]

25. Lawal, S.A.; Choudhury, I.A.; Nukman, Y. Developments in the formulation and application of vegetable oil-based metalworking fluids in turning process. Int. J. Adv. Manuf. Technol. 2013, 67, 1765-1776. [CrossRef]

26. Debnath, S.; Reddy, M.M.; Yi, Q.S. Environmental friendly cutting fluids and cooling techniques in machining: A review. J. Clean. Prod. 2014, 83, 33-47. [CrossRef]

27. Sharma, V.S.; Dogra, M.; Suri, N.M. Cooling techniques for improved productivity in turning. Int. J. Mach. Tools Manuf. 2009, 49, 435-453. [CrossRef]

28. Serope, K.; Schmid, S.R. Manufacturing Engineering and Technology, 4th ed.; Prentice Hall: Bergen County, NJ, USA, 2001.

29. Pathan, A.; Kadam, M. Experimental study on effect of cutting parameters on chip-tool interface temperature and chip formation in turning en-31 hardened steel under flooded and mql conditions. Int. J. Innov. Sci. Eng. Technol. 2015, 2, 724-729.

30. Koen, D. Investigation of a Novel Cooling Methods to Enhance Aerospace Component Manufacturing Practices. Master's Thesis, Stellenbosch University, Stellenbosch, South Africa, 2011.

31. Vagnorius, Z.; Sørby, K. Effect of high-pressure cooling on life of sialon tools in machining of inconel 718. Int. J. Adv. Manuf. Technol. 2011, 54, 83-92. [CrossRef]

32. Busch, K.; Hochmuth, C.; Pause, B.; Stoll, A.; Wertheim, R. Investigation of cooling and lubrication strategies for machining high-temperature alloys. Procedia CIRP 2016, 41, 835-840. [CrossRef]

33. Upadhyay, V.; Jain, P.; Mehta, N.; Branko, K. Minimum quantity lubrication assisted turning-An overview. DAAAM Int. Sci. Book 2012, 39, 463-479.

34. Benedicto, E.; Carou, D.; Rubio, E.M. Technical, economic and environmental review of the lubrication/ cooling systems used in machining processes. Procedia Eng. 2017, 184, 99-116. [CrossRef]

35. Shokrani, A.; Dhokia, V.; Newman, S.T. Environmentally conscious machining of difficult-to-machine materials with regard to cutting fluids. Int. J. Mach. Tools Manuf. 2012, 57, 83-101. [CrossRef]

36. Iturbe, A.; Hormaetxe, E.; Garay, A.; Arrazola, P.J. Surface integrity analysis when machining inconel 718 with conventional and cryogenic cooling. Procedia CIRP 2016, 45, 67-70. [CrossRef]

37. Ribeiro Filho, S.L.M.; Vieira, J.T.; de Oliveira, J.A.; Arruda, É.M.; Brandão, L.C. Comparison among different vegetable fluids used in minimum quantity lubrication systems in the tapping process of cast aluminum alloy. J. Clean. Product. 2017, 140, 1255-1262. [CrossRef]

38. López de Lacalle, L.N.; Angulo, C.; Lamikiz, A.; Sánchez, J.A. Experimental and numerical investigation of the effect of spray cutting fluids in high speed milling. J. Mater. Process. Technol. 2006, 172, 11-15. [CrossRef]

39. Pereira, O.; Català, P.; Rodríguez, A.; Ostra, T.; Vivancos, J.; Rivero, A.; López-de-Lacalle, L.N. The use of hybrid co2+mql in machining operations. Procedia Eng. 2015, 132, 492-499. [CrossRef]

40. MULYADI, I.H. Improving the performance of minimum quantity lubrication in high speed milling and environmental performance analysis. Ph.D. Thesis, University of Manchester, Manchester, UK, 2013.

41. Vazquez, E.; Gomar, J.; Ciurana, J.; Rodríguez, C.A. Analyzing effects of cooling and lubrication conditions in micromilling of ti6al4v. J. Clean. Product. 2015, 87, 906-913. [CrossRef]

42. Liu, Z.; Cai, X.; Chen, M.; An, Q. Investigation of cutting force and temperature of end-milling Ti-6Al-4V with different minimum quantity lubrication (MQL) parameters. Proc. Inst. Mech. Eng. Part B J. Eng. Manuf. 2011, 225, 1273-1279. [CrossRef]

43. Balaji, A.; Rakurty, C.; Montemayor, H.; Ghatikar, V. A novel multiple cutting fluid dispensing system for sustainable manufacturing. In Proceedings of the 2014 STLE Annual Meeting \& Exhibition, Lake Buena Vista, FL, USA, 18-22 May 2014. 
44. Webster, J.A. Improving surface integrity and economics of grinding by optimum coolant application, with consideration of abrasive tool and process regime. Inst. Mech. Eng. Part B J. Eng. Manuf. 2007, 221, 1665-1675. [CrossRef]

45. Irani, R.A.; Bauer, R.J.; Warkentin, A. A review of cutting fluid application in the grinding process. Int. J. Mach. Tools Manuf. 2005, 45, 1696-1705. [CrossRef]

46. Mike, M.; Vadim, B.J. On the coherent length of fluid nozzles in grinding. Key Eng. Mater. 2009, 404, 61-67.

47. Edward, M.T.; Wright, P.K. Metal Cutting, 4th ed.; Butterworth-Heinemann: Oxford, UK, 2000.

48. David, A.S.; Agapoiu, J.S. Metal Cutting Theory and Practice, 2nd ed.; CRC Press Taylor \& Francis: Boca Raton, FL, USA, 2006; p. 19.

49. Liu, J.; Ren, C.; Qin, X.; Li, H. Prediction of heat transfer process in helical milling. Int. J. Adv. Manuf. Technol. 2014, 72, 693-705. [CrossRef]

50. Sato, M.; Tamura, N.; Tanaka, H. Temperature variation in the cutting tool in end milling. J. Manuf. Sci. Eng. 2011, 133, 021005. [CrossRef]

51. Cui, X.; Guo, J. Effects of cutting parameters on tool temperatures in intermittent turning with the formation of serrated chip considered. Appl. Therm. Eng. 2017, 110, 1220-1229. [CrossRef]

52. Grzesik, W. Chapter Nine-Heat in metal cutting. In Advanced Machining Processes of Metallic Materials, 2nd ed.; Elsevier: Amsterdam, The Netherlands, 2017; pp. 163-182.

53. Karaguzel, U.; Bakkal, M.; Budak, E. Modeling and measurement of cutting temperatures in milling. Procedia CIRP 2016, 46, 173-176. [CrossRef]

54. Metzger, J.L. Superabrasive Grinding; Butterworths: London, UK, 1986; p. 134.

55. Aerospace-Titanium Machining Guide-Kennametal. Available online: https://www.kennametal. com/content/dam/kennametal/kennametal/common/Resources/Catalogs-Literature/Industry\% 20Solutions/Titanium_material_machining_guide_Aerospace.pdf (accessed on 15 April 2016).

56. Boothroyd, G.; Knight, W.A. Fundamental of Machining and Machine Tool, 3rd ed.; CRC Press Francis \& Taylor: Boca Raton, FL, USA, 2005.

57. Sandvik, C. Modern Metal Cutting-A Practical Handbook, 1st ed.; AB Sandvik Coromant: Sandviken, Sweden, 1994; p. x-21.

58. Luchesi, V.M.; Coelho, R.T. Experimental investigations of heat transfer coefficients of cutting fluids in metal cutting processes: Analysis of workpiece phenomena in a given case study. Proc. Inst. Mech. Eng. Part B J. Eng. Manuf. 2012. [CrossRef]

59. Webster, J.A. Coolant calculus. In Cutting Tool Engineering; Cool-Grind Technologies LLC: Ashford, CT, USA, February 2008; p. 8.

60. Ezugwu, E.O. Key improvements in the machining of difficult-to-cut aerospace superalloys. Int. J. Mach. Tools Manuf. 2005, 45, 1353-1367.

61. Park, K.-H.; Yang, G.-D.; Lee, M.-G.; Jeong, H.; Lee, S.-W.; Lee, D.Y. Eco-friendly face milling of titanium alloy. Int. J. Precis. Eng. Manuf. 2014, 15, 1159-1164. [CrossRef]

62. Hadzley, A.B.M.; Izamshah, R.; Sarah, A.S.; Fatin, M.N. Finite element model of machining with high pressure coolant for Ti-6Al-4V alloy. Procedia Eng. 2013, 53, 624-631. [CrossRef]

63. da Silva, R.B.; Machado, Á.R.; Ezugwu, E.O.; Bonney, J.; Sales, W.F. Tool life and wear mechanisms in high speed machining of Ti-6Al-4V alloy with pcd tools under various coolant pressures. J. Mater. Process. Technol. 2013, 213, 1459-1464. [CrossRef]

64. Cai, X.J.; Liu, Z.Q.; Chen, M.; An, Q.L. An experimental investigation on effects of minimum quantity lubrication oil supply rate in high-speed end milling of Ti-6Al-4V. Proc. Inst. Mech. Eng. Part B J. Eng. Manuf. 2012. [CrossRef]

65. Shyha, I.S.; Soo, S.L.; Aspinwall, D.K.; Bradley, S.; Perry, R.; Harden, P.; Dawson, S. Hole quality assessment following drilling of metallic-composite stacks. Int. J. Mach. Tools Manuf. 2011, 51, 569-578. [CrossRef]

(C) 2017 by the authors. Licensee MDPI, Basel, Switzerland. This article is an open access article distributed under the terms and conditions of the Creative Commons Attribution (CC BY) license (http://creativecommons.org/licenses/by/4.0/). 